\title{
Marketing Ethics at Islamic Banks: Principles and Practices
}

\author{
M. Qoshid Al Hadi ${ }^{1}$, Eko Nur Cahyo ${ }^{2}$, Iman Setya Budi ${ }^{1}$ \\ ${ }^{1}$ University of Islam Kalimantan MAB \\ ${ }^{2}$ Coventry University, UK \\ email: mqoshidalhadi@uniska-bjm.ac.id, ekonuralmalowy@ \\ gmail.com, aymannoordin@gmail.com
}

\begin{abstract}
This article highlights the principles and implementation of Islamic banking marketing ethics. Ethics based on sharia principles are an essential differentiator from their competitors. It begins from the 4 P's marketing mix framework, namely product, price, promotion, and place. This article is qualitative descriptive research using literature review. This article employs secondary data from 11 articles. The data that has been collected then analyzed with descriptive information. Therefore, through 4 P's marketing mix lens, this article finds a lack of ethical marketing practices in Islamic Banking from the ethical ideals espoused in the literature. This study analyzes the ethical marketing practices of Islamic banks which can be used as an evaluation of policies in the Islamic financial industry.
\end{abstract}

Keywords: Marketing Mix, Islamic Banks, Marketing Ethics, Marketing Practice.

\section{INTRODUCTION}

Amid the collapses and bail-outs of 2008, Islamic banking has received sharp scrutiny for its ability to withstand the shocks of the crisis (Schottmann, 2014). Islamic Finance Development Indicator, (2020) reports that annual growth of Islamic banking assets in 2019 reported 14\%. Meanwhile, the share of Islamic banking as a percentage of total banking in GCC countries increased from $31 \%$ in 2008 or after the crisis to $45 \%$ in 2017 . The Islamic banking sector has grown at an annual rate of around 
$17 \%$ during 2009-2013, which includes the period of the post2008 global crisis (Elmawazini et al., 2020).

Academics consider Islamic banks' development to be potential and have a bright future because Islamic banks offer a different value than the previous bank (conventional) (Musa et al., 2020). Some argue that the different values presented by Islamic banking are a moral alternative based on upholding the values of justice, equity and welfare (Mansour et al., 2015). For this reason, Islamic banking is required to have a sharia board to ensures all activities comply with the rules of sharia law and ethics (Hamza, 2013). Because these ethical values are expected to observe the prohibition of usury, uncertainty and gambling. This ethical value also wants to tie between financial transactions and activities in the real economy. (Nienhaus, 2011).

Although Islamic banking relies heavily on the loyalty of their customers (Fianto et al., 2020), they have not been able to emphasize the unique quality of the services they provide (Wilson, 2002). Sonko (2020) found the most of his respondents believe that the AGIB bank in Gambia was not sharia-compliant. Although it cannot be generalized, Islamic banks often promote themselves as an ethical financial services that have not been able to explain explicitly what is meant by ethics (Wilson, 2002). The word ethics is used as a label and equated with Islam but there has been no serious attempt to link what is ethical with financial activity. Due to the presence of Islamic banks with their unique ethical values along with banking rules in general, this ultimately makes this bank difficult and Islamic banks need a more accurate explanation for customer satisfaction (Mansour et al., 2015)

The agenda for maintaining customer satisfaction in the banking industry continues to be intensified by improving relationships with customers and building their trust with bank employees (Ozatac et al., 2016). Previous studies have done Islamic banking to strengthen their existence. Such as intensifying knowledge to leads the use of intellectual capital. Because the task of a bank relies on creativity, offering sophisticated edge products and providing exceptional service to customers (Ur Rehman et al., 2021). Attempt to meet customer satisfaction are 
also executed by Islamic banks through internal marketing which is proven through research by Bruin et al., (2020) that internal promotion, internal process and internal propose are enablers of employee's perceived ability to deliver service quality in the Islamic Banking. In order to transmit the values of Islamic banks to the community, the role of marketing becomes vital.

The vital nature of the marketing concept as the idea of creating value for customers, companies and society has the potential to be undermined by the realities of market practice. Because every marketing activity is driven by certain individuals or groups and the motives, intentions, goals, capabilities and culture of the entity are very different. The risk can be detrimental to all existing stakeholders (Wozniczka, 2016). For this reason, this article tries to capture published research about ethical marketing in order to evaluate the performance of Islamic banking in building its existence through fundamental marketing mix (product, price, place and promotion).

Islamic banking as a new financial institution must be able to compete and adapt to the global business environment. As a financial institution that carries moral ideas in every activity, Islamic banking requires human resources, rules and an environment that can substantially support innovation.

To bridge the gap, the present study proposed to analyses the marketing ethics in Islamic banking. The analysis will now review marketing ethics from the existing literatures. The study's design focused on answering the following research question: how has the ethical ideal adopted by the Islamic marketing ethics literature sufficiently reflected in Islamic bank marketing practices?

\section{LITERATURE REVIEW \\ History of the Development Marketing Ethics}

The history of marketing ethics began when concerns surfaced about antitrust and consumer protection in the early 20th century. At that time, several studies from books and scientific journals discussed fair service to seller's principles. The studies developed into a book about marketing ethics, in which there is an ethics of bargaining and fair pricing. Since then (the 1950s), 
many scholars have commenced to focus on healthy and fair trade studies, antitrust, pricing, advertising, or promotion (Caner \& Banu, 2014).

In the 1960s, ecological problems such as pollution and waste spread in major U.S. cities. The problem was caused by a culture of consumerism that plagued Americans at the time. Finally, in 1962, the United States president, John F. Kennedy, declared a special message to protect consumers. Four consumer rights must be fulfilled; the right to security, the right to information, the right to vote, and the right to be listened to.

Furthermore, Caner \& Banu (2014) mentioned that in the 1970 s, research in the field of ethics was significantly conducted by researchers such as Carroll (1975), Bowman (1976), Farrell and Weaver (1978). These studies generate new insights into organizational relationships in terms of the ethics and behavior of marketing managers. This empirical research provides the foundation of a framework that explains ethical policymaking in marketing organizations.

In 1989, research conducted by Hunt, Wood and Chonko concluded that efficiency, productivity and success were at the core of the overall discipline, and marketing dimension. However, companies that promote high ethical values in the organization can find themselves richer in terms of loyalty than other companies that ignore ethical values. Even culturally different companies can survive in a highly competitive international arena if they uphold solid ethical values (Hunt et al., 1989).

In 1993, marketing studies' development came in on the implications for a marketer who expects a more relational transaction to apply ethical values in decision-making. Building trust and developing solid responsibilities and commitments seem to be an important exchange dimension for the company (Gundlach \& Murphy, 1993).

Based on research on the history of marketing developments, many studies have been done over the last 20 years. Several books on the theme of marketing relationships have been published in Europe, such as Hougaard in 2004 entitled Strategic Relationship Marketing and Buttle in 2004 on Customer 
Relationship Management: Concepts and Tools. Likewise, in North America, like Barnes in 2001, who published Secrets of Customer Relationship Management: It's All About How You Make Them Feel. According to Murphy et al., there has been a significant paradigm change in marketing because of the many studies on marketing. That change leads to explicit aspects no longer implicit (Murphy et al., 2007).

In the last 20 years, other studies also have recognized that positive research is more dominant than normative. This means that researchers develop theories and mottos that seek to describe, explain and predict ethical phenomenon such as ethical judgment, intention, behavior, and various problems. Most positive studies use scenarios to explore reactions from the subject's behavior to situations that have been designed or predetermined by researchers to determine the ethics or behavior that will occur (Chonko \& Hunt, 2000). From this, the author realizes that sharia marketing ethics is running in the same pattern, which is a pattern that has been passed by conventional marketing ethics. The author will continue to focus on the ethics of Islamic bank marketing that will be the purpose of this article written.

\section{Islamic Bank Marketing Ethics}

Beekun (1997) defines ethics as a set of moral principles that distinguish between right and wrong. Ethics is a normative area because it regulates what to do and what not to do. The term ethics is very similar to khuluq contained in the Quran. Al Quran also uses other terms to describe goodness: al khayr, al birr, al qist, al 'adl, al haqq, al ma'ruf, and taqwa.

The Islamic approach to business ethics has been governed by the Quran and sunnah. Even Saeed et al. (2001), judging it is absolute. Since then, Islamic practices, including marketing, have been based on divinity and faith. Islam does not separate worldly and spiritual affairs. Sometimes these two things often occur in the conflict in a Western perspective based on the principle of maximizing profit. This is in contrast to Islam, which emphasizes the maximizing of values. 
According to Saeed et al. (2001), the value that Islam offers in marketing ethics is justice. Many Muslim scholars analyze justice in marketing by categorizing it as fair play and just dealing. Kamla \& Rammal (2013) concluded in their theoretical analysis that social justice is a core value in Sharia and Islamic teachings. Islamic financial and economic literature is widely recognized as dominated by ideas that advocate Islamic finance's role should shape broader social goals and is intended to address the injustices and inequalities created by the capitalist system.

Islamic marketing ethics based on maximizing value requires empathy for others as a reflection of nature and God. Empathy will be reflected in the refrain from transactions that harm others and avoid unethical marketing practices (Hamid \& Zubair, 2019). Of the many illegal practices, the basic principles that lead to Islamic banking financial transactions are maisir (gambling), gharar (uncertain information), and riba (bank interest) (Rashid $\&$ Hassan, 2014). All of these practices have the potential to harm one of the transacting parties.

Kamarulzaman \& Madun (2013) emphasized the importance of Islamic banks should understand their customers' expectations. It is an imperative strategy for Islamic bankings to know the value and quality that customers expect from the bank. Then Rashid \& Hassan (2014) added that Islamic banks' attractiveness is their commitment to emphasize profit and loss sharing contracts and development of social activities in the form of zakat, infaq, shodaqoh and qordul hasan.

Many scholars believe that Islamic finance will grow by considering the future of the world's more prosperous Muslim countries. As well as the prospects of the financial industry's challenges, Islamic banks can reconcile the discrepancies between the theology and modern portfolio theory (Khaki \& Sangmi, 2012).

According to Dasuki and Abdullah, cited by Riaz (2016), the Islamic bank system has united between promotional ethics and social responsibility. Because, in fact, the bank is a business based on ethics and trust. Therefore, the public pawn its responsibility to the bank managers to regulate their interests legally and ethically. 
In Islamic banking, ethics is a fundamental identity because it is based on business partnerships, and the condition is above the relationship of just customers and banks. That ethical identity also includes adherence to sharia (Rashid \& Hassan, 2014).

Previous studies have also discussed marketing ethics from an Islamic perspective applied in the banking industry (Beekun \& Badawi, 2005). Furthermore, a study highlights that the new model in Islamic marketing ethics is the character of value maximization instead of profit maximization carried out by conventional marketing (Abbas et al., 2019). The author believes that Islamic marketing ethics that apply value maximization are relevant to the financial industry, whose base is a belief institution. However, in the study of Islamic bank marketing ethics, the author obtained limited conceptual studies and the early era of conventional marketing ethics studies. The study of sharia bank marketing ethics is generally still implicit and normative. However, the authors felt that this study was part of conceptual maturation that would be the foundation of further research.

\section{Illegal Practice in Marketing}

Previous research has shown there are many cases of unethical marketing. The practice is manifested in the form of false advertising, forced selling, unsafe or harmful products, deceptive or dubious prices, deceptive communications, bribery, deceptive distribution, and the promotion of materialism. This can be analyzed through the approach of the marketing mix (Riaz, 2016).

In the comments to the Ethics and Marketing Management article, Chonko \& Hunt (2000) concluded that many marketers face bribery problems. There are five issues considered the most difficult issues: fairness, honesty, pricing strategies, product strategies, and personal decisions. The main ethical conflict faced by marketers is balancing the company's demand and buyer's needs. Marketer managers sense many opportunities within the company to commit unethical acts.

Baumhart, cited by Chonko \& Hunt (2000), mentions the results of five ethical testing issues that many practitioners want 
to eliminate including as follows (1) gifts, gratuities, bribes, and women's calls; (2) unfair price and price discrimination; (3) dishonest promotion; (4) deceive customers; (5) price collusion.

While the findings of Chonko and Hunt (1989) there are 10 most suited ethicssuch as (1) bribery, (2) fairness, (3) honesty, (4) price, (5) product, (6) personnel/personal, (7) confidentiality, (8) data manipulation, (9) advertising, (10) shopping. Such misconduct activities can directly harm consumers. Dishonesty can cause long-term negative effects, including distrust and suspicion of any marketing activity.

Here is a table of unethical practices based on their work area:

Table 1. Unethical Practices in Marketing

\begin{tabular}{ll}
\hline \multicolumn{1}{c}{ Scope } & \multicolumn{1}{c}{ Unethical Practices } \\
\hline Product & - Offering products that are prohibited and \\
& - - Bangerous \\
& - Prand abuse practices \\
& - Fake products \\
& - Arbitrary product deletion \\
& - Change product quality and size to keep it at \\
& - the same level \\
- Expensive and unreasonable prices \\
- Pricing & Predatory prices that force other products to \\
& - Set prices high \\
& - Price collusion \\
& - Offer different prices with different buyers \\
- Pressuring targeted marketers \\
- Unfair treatment of buyers/customers \\
- Corrupt pricing policies \\
- Marketers deceptive practices \\
- Marketers who do not keep promises \\
- Not responsive to buyer/customer complaints \\
\hline
\end{tabular}




\begin{tabular}{|c|c|}
\hline Scope & Unethical Practices \\
\hline $\begin{array}{l}\text { Buyermanagement } \\
\text { and database }\end{array}$ & $\begin{array}{l}\text { - Different treatment of buyers } \\
\text { - Misuse of information } \\
\text { - The invasion of privacy of the information the } \\
\text { buyer/customer } \\
\text { - Collecting and selling buyer/customer data } \\
\text { without the buyer's /customer's knowledge } \\
\text { - Bind buyers/customers to contracts and } \\
\text { - } \text { confuse them } \\
\text { - Faising or adding hidden fees }\end{array}$ \\
\hline $\begin{array}{l}\mathrm{M} \text { a } \mathrm{r} \mathrm{k} \text { e } \mathrm{t} \text { i } \mathrm{n} \mathrm{g} \\
\text { communications }\end{array}$ & $\begin{array}{l}\text { - Deceptive advertising } \\
\text { - Advertising interruptions } \\
\text { - Indifferent or ignorant of promotions } \\
\text { - Made-up and exaggerated claims } \\
\text { - Omitting information on products } \\
\text { - Promoting products with bribes } \\
\text { - Using advertising messages that contain } \\
\text { - } \text { Insulting feelings of religion and state } \\
\text { - Stereotyping minorities and gender }\end{array}$ \\
\hline Online marketing & $\begin{array}{l}\text { - Manipulate buyers/customers } \\
\text { - Contacting people without their consent and } \\
\text { spamming } \\
\text { - Interference with online advertising } \\
\text { - Promote and sell banned products online } \\
\text { - Manipulating social media in }\end{array}$ \\
\hline
\end{tabular}

Source: adapted from (Wozniczka, 2016)

\section{METHODS}

This article is qualitative research using review literature. Literature review is important to find out the purpose and contribution of the conducted research published on articles. Generally, Palmatier et al., (2018) stated that the objectives of the review were 1) solving ambiguity of definitions and making an outline of the topics discussed, 2) providing an integrated and synthesized picture of the current state of knowledge, 3) identifying inconsistencies the previous results and potential 
explanations, 4) evaluating existing methodological approaches and unique insights, 5) developing a conceptual framework to reconcile and expand on previous research, 6) describing research insights, existing gaps, and future research directions.

In this case, the authors used the integrative review introduced by Snyder (2019). The integrative review is a research method by collecting relevant previous research by explaining the identification process and critically assessing these researches. What distinguishes it from systematic review is that integrative reviews have different objectives, including to assess, criticize and synthesize literature with research topics that allow for a new framework or perspective.

However, the authors have limitations in the number of relevant articles. So, authors had used several variations in the search keywords for the article. The authors suppose that there are not many studies that focus on the marketing mix in Islamic banking, so it is difficult to find articles that are worth re-viewing.

Furthermore, the authors followed the three-step approach suggested by the researcher (Snyder, 2019). First, designing a review, the design review that authors adopt an integrative review which aims to conclude or evaluate a large field, namely product, price, promotion and place (marketing mix). Here the authors use the term "Islamic Bank Marketing Mix" via google scholar, we find 17,400 results from 2011 to 2021 . However, not all of these articles are relevant to our research objectives and the limitation of time, the authors completed the research on 11 articles.

The second step is after determining the objectives and keywords, the authors start to sort out the relevant articles to be classified into sub product, price, promotion and place. The results are articles about products that we can review from (Abbas et al., 2019; Kamarulzaman \& Madun, 2013; Rahayu et al., 2020; Riaz, 2016) furthermore related to the price of relevant articles that we can review, (E. R. Ahmed et al., 2018; Rahayu et al., 2020; Rama, 2020). Then in the sub-promotion the relevant articles that we can review are (S. Ahmed \& Rahman, 2015; Kader et al., 2015; Naeem, 2019). Finally, the places in marketing mix, we review from (Alquradaghi, 2013; Kader et al., 2015; Naeem, 2019; Riaz, 
2016).

From 11 articles that we reviewed, there were 9 articles indexed by Scopus, 1 indexed by WOS and the last one was accredited by the International Press Registry (USA). Therefore, we believe in the quality of the articles we select.

The third step is analysis. The authors analyzed the articles one by one by concluding and assessing the issues relevant to our research. Figure 1 provides summary of three steps mentioned that explain analysis process. The last is writing a review with a $4 \mathrm{p}$ marketing mix structure. Table 2 provides articles used to reviewing.

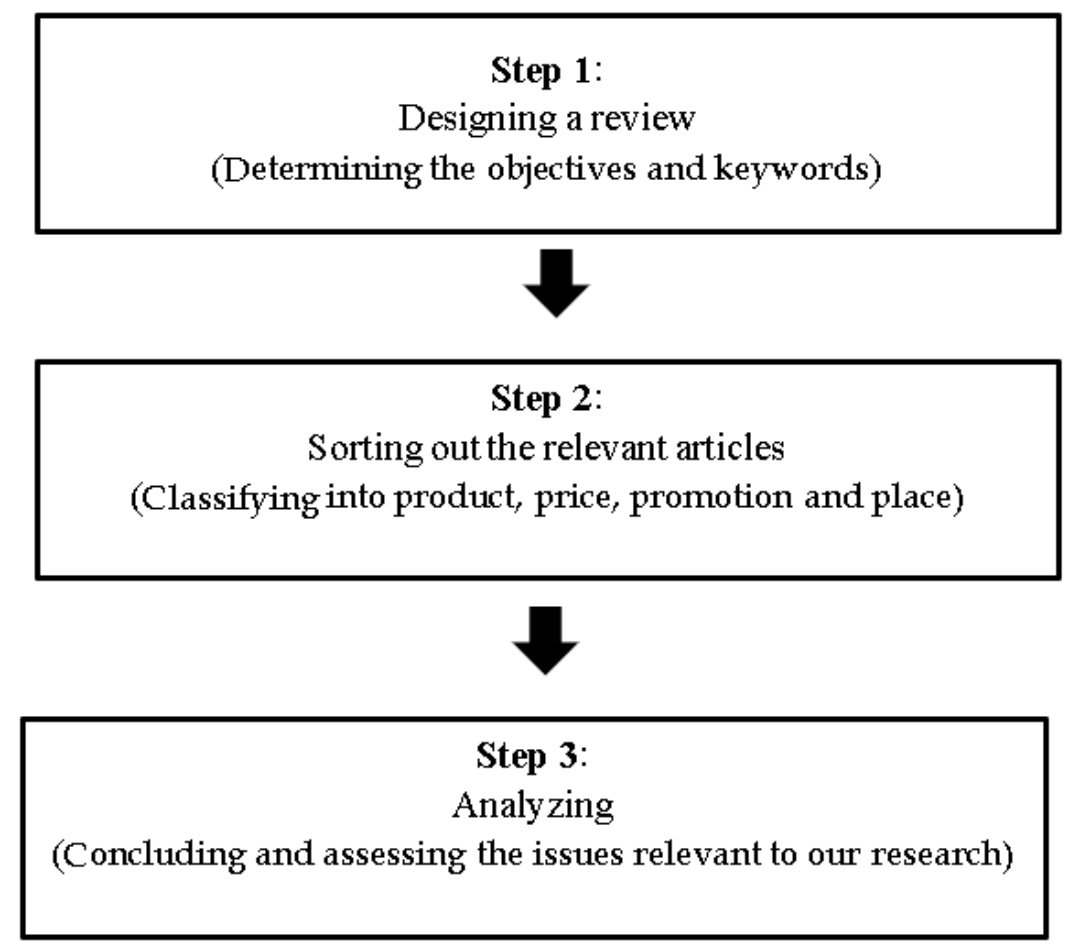

Figure 1. Analysis Process 
Table 2. Articles used in the process of reviewing

\begin{tabular}{|c|c|c|c|}
\hline Sub & Author & Title & Journal \\
\hline \multirow[t]{4}{*}{ Product } & (Abbas et al., 2019) & $\begin{array}{l}\text { The role } \\
\text { of Islamic } \\
\text { marketing ethics } \\
\text { towards customer } \\
\text { satisfaction }\end{array}$ & $\begin{array}{l}\text { Journal } \\
\text { of Islamic } \\
\text { Marketing }\end{array}$ \\
\hline & $\begin{array}{l}\text { (Kamarulzaman \& } \\
\text { Madun, 2013) }\end{array}$ & $\begin{array}{l}\text { Marketing } \\
\text { Islamic banking } \\
\text { products: } \\
\text { Malaysian } \\
\text { perspective. }\end{array}$ & $\begin{array}{l}\text { Business } \\
\text { Strategy Series }\end{array}$ \\
\hline & (Rahayu et al., 2020) & $\begin{array}{l}\text { Migration } \\
\text { (Hijra) to Islamic } \\
\text { bank based } \\
\text { on push-pull- } \\
\text { mooring theory : } \\
\text { a services } \\
\text { marketing mix } \\
\text { perspective }\end{array}$ & $\begin{array}{l}\text { Journal } \\
\text { of Islamic } \\
\text { Marketing }\end{array}$ \\
\hline & (Riaz, 2016) & $\begin{array}{l}\text { Islamic } \\
\text { Marketing } \\
\text { Ethics and } \\
\text { the Marketing } \\
\text { Practices of } \\
\text { Islamic Banks }\end{array}$ & $\begin{array}{l}\text { ISRA } \\
\text { International } \\
\text { Journal of } \\
\text { Islamic Finance }\end{array}$ \\
\hline \multirow[t]{2}{*}{ Price } & $\begin{array}{l}\text { (E. R. Ahmed et al., } \\
\text { 2018) }\end{array}$ & $\begin{array}{l}\text { Proposed the } \\
\text { pricing model } \\
\text { as an alternative } \\
\text { Islamic } \\
\text { benchmark }\end{array}$ & Benchmarking \\
\hline & (Rahayu et al., 2020) & $\begin{array}{l}\text { Migration } \\
\text { (Hijra) to Islamic } \\
\text { bank based } \\
\text { on push-pull- } \\
\text { mooring theory : } \\
\text { a services } \\
\text { marketing mix } \\
\text { perspective }\end{array}$ & $\begin{array}{l}\text { Journal } \\
\text { of Islamic } \\
\text { Marketing }\end{array}$ \\
\hline
\end{tabular}




\begin{tabular}{|c|c|c|c|}
\hline Sub & Author & Title & Journal \\
\hline \multirow{4}{*}{ Promotion } & $\begin{array}{l}\text { (S. Ahmed \& Rahman, } \\
\text { 2015) }\end{array}$ & $\begin{array}{l}\text { Strategic pricing } \\
\text { by Islamic banks } \\
\text { and the impact } \\
\text { on customer } \\
\text { satisfaction } \\
\text { and behavioral } \\
\text { intention }\end{array}$ & $\begin{array}{l}\text { Journal } \\
\text { of Islamic } \\
\text { Accounting } \\
\text { and Business } \\
\text { Research }\end{array}$ \\
\hline & $\begin{array}{l}\text { (S. Ahmed \& Rahman, } \\
\text { 2015) }\end{array}$ & $\begin{array}{l}\text { the Effects of } \\
\text { Marketing Mix } \\
\text { on Consumer } \\
\text { Satisfaction: } \\
\text { a Literature } \\
\text { Review } \\
\text { From Islamic } \\
\text { Perspectives }\end{array}$ & $\begin{array}{l}\text { Turkish Journal } \\
\text { of Islamic } \\
\text { Economics }\end{array}$ \\
\hline & $\begin{array}{l}\text { (Kader et al., 2015)its } \\
\text { returns and its physical } \\
\text { image. Analysis of } \\
\text { Variance (ANOVA }\end{array}$ & $\begin{array}{l}\text { Why This } \\
\text { Bank? : } \\
\text { Understanding } \\
\text { Customers' } \\
\text { Preference for } \\
\text { an Islamic Bank } \\
\text { in a Competitive } \\
\text { Market }\end{array}$ & $\begin{array}{l}\text { Journal } \\
\text { of Islamic } \\
\text { Economics } \\
\text { Banking and } \\
\text { Finance }\end{array}$ \\
\hline & (Naeem, 2019) & $\begin{array}{l}\text { Understanding } \\
\text { the role of social } \\
\text { networking } \\
\text { platforms in } \\
\text { addressing the } \\
\text { challenges of } \\
\text { Islamic banks }\end{array}$ & $\begin{array}{l}\text { Journal of } \\
\text { Management } \\
\text { Development }\end{array}$ \\
\hline \multirow[t]{2}{*}{ Place } & (Alquradaghi, 2013) & $\begin{array}{l}\text { The } 7 \text { Ps` In } \\
\text { the Websites of } \\
\text { Qatari Banks }\end{array}$ & $\begin{array}{l}\text { Journal of } \\
\text { Management and } \\
\text { Science }\end{array}$ \\
\hline & (Kader et al., 2015) & $\begin{array}{l}\text { Why This } \\
\text { Bank? : } \\
\text { Understanding } \\
\text { Customers' } \\
\text { Preference for } \\
\text { an Islamic Bank } \\
\text { in a Competitive } \\
\text { Market }\end{array}$ & $\begin{array}{l}\text { Journal } \\
\text { of Islamic } \\
\text { Economics } \\
\text { Banking and } \\
\text { Finance }\end{array}$ \\
\hline
\end{tabular}




\begin{tabular}{llll}
\hline Sub & \multicolumn{1}{c}{ Author } & \multicolumn{1}{c}{ Title } & \multicolumn{1}{c}{ Journal } \\
\hline & (Naeem, 2019) & Understanding & Journal of \\
& & the role of social & Management \\
& networking & Development \\
& platforms in & \\
& addressing the & \\
& challenges of & \\
& Islamic banks & \\
& Islamic & ISRA \\
& Marketing & International \\
& Ethics and & Journal of \\
& the Marketing & Islamic Finance \\
& & Practices of & \\
& Islamic Banks & \\
& &
\end{tabular}

\section{RESULTS AND DISCUSSION}

Each company has its own favorite marketing mix. Some apply 4 Ps, 7 Ps and others 10 Ps. The first time the 4 Ps concept in the marketing mix was introduced by Rasmussen then developed by Kotler. The marketing mix with the 4 Ps is a basic concept that was only introduced in the 1960s. After that it was converted into a field of research and theoretical foundation building (Thabit \& Raewf, 2018)price, place or distribution, and promotion. Following the development 4 Ps today that has evolved into 10 Ps (product, price, place, promotion, people, process, physical evidence, packaging, partnerships, and policies). 10 Ps was setted by Lim, (2020) to meet customer needs and serve competitiveness for successful marketing penetration. By considering the depth of understanding, details and time in research, this article will take the fundamental part of marketing, namely 4 Ps.

\section{Product}

A service product consists of all the intangible and tangible offered and adds value to the customer. In the context of Islamic banking, knowledge of Muslim interest in Islamic banks is essential. They will be interested if Islamic banks' services and profits are the same as their competitors as conventional banks. Judging from the product aspect, previous research has shown that customers feel Islamic banking products and 
services should be under sharia principles. Similarly, Islamic banks' ability to convince customers that the institution has fully adhered to sharia principles. That will prevent customers from moving to their competitors' banks (Rahayu et al., 2020).

Al Ukhuwa, cited by Abbas et al. (2019), mentions five business ethics principles under products. First, the product is not an illegal item that can damage one's mind or make a fool. Second, the product must have the assets behind it. Third, the product must be something that can be handed over. Otherwise, the product is considered invalid or valid. Fourth, additional charge features are allowed if the product undergoes changes or additions. Fifth, all parties are responsible for fulfilling their obligations in good faith and whatever is done must be based on Islamic principles of justice, equality and fairness.

Kamarulzaman \& Madun (2013) found that Islamic bank products in Malaysia are still difficult to be known or familirized by the community. The product information to the customers needs to be disclosed so that they can validate and assess the product themselves. The first facility used is an Islamic bank web that can provide useful product information and help customer satisfaction. Second, some cases where the vanguard of Islamic banks are not very knowledgeable about Islamic bank products. As a result, they failed to market them effectively. Third, there are conventional banks that operate Sharia banks in one window. This means that the same resources serve two very different products. Therefore, the banks should possess the skilled resources.

In the previous research, two aspects of the product criticized by Riaz (2016) are related to the advantages with costplus methods in product development and dependence of Islamic banks in repackaged conventional bank products to be adjusted to sharia principles. This study's results are interesting because almost $80 \%$ of Sharia banks' financial transactions are based on debt contracts, while equitybased financing only covers $20 \%$ of all transactions. This 
happens because Islamic banks repackage conventional bank products so that the mindset of maximizing profit rather than benefit is also attached to Islamic banks. Meanwhile, short-term debt amounts to more than the long term. If it is viewed from the purpose of debt or financing, the short term is more consumptive than the long-term purpose is generally for the investment or the development. Therefore, from the financing structure, Sharia banks are considered still stuck in profit-oriented instead of benefit.

2. Price

From a customer perspective, Zeithmal in Rama (2020) argues that price is a "give" component, not a "get/receive" component. The price component is divided into two, namely perceived price and objective price. The objective price is the product or service's actual price, while the perceived price is the price encoded by the customer. In the banking industry, prices are complex and heterogeneous. Banks charge fees for services and use interest charges on loans and pay certain types of accounts. The service industry's price categories include prices, tariffs, fees, fees, surcharges, service fees, penalties, quotes, coupons, or price promotions.

Empirical findings by Rama, (2020) revealed that customers experienced greater price expectations in the decision making process. The amount and complexity of price expectations depend primarily on customer interest, especially price transparency, relative price, and price-quality ratio. Islamic banking customers in Indonesia are highly aware of price transparency, have "relative thinking" to price differences, and put price-quality ratios in their assessments.

Conceptually, however, there is a difference between conventional banks and Islamic banks, including price. In Islamic banks, the practice of usury or bank interest is strictly prohibited in the Quran. Therefore the bank's interest mechanism is transferred into sharia-compliant financing modes with different incentives to fund providers and their users. 
Over the last three decades, research has consistently shown that prices at Islamic banks are higher than conventional banks. For example, the cost of a mortgage in an Islamic bank is prohibitive and is considered exploitation on behalf of Sharia. The main reason revealed by Riaz (2016) on why Islamic bank prices are higher is the cost of "sharia" premiums. With the sharia label, customers are promised to avoid transactions that are prohibited. To get the sharia label, there is an additional fee charged to the bank's operations, namely the salaries of several Sharia professionals who are experts in the field of Islamic financial law (Riaz, 2016).

Meanwhile, according to Rahayu's research, many Muslim consumers will be interested in switching to Islamic banks if they offer high profits, low perceived costs, perceived benefits, and low service costs. Ironically Muslim customers have not tended to switch to Islamic banks because of the offer of lower returns than conventional banks. Also, prospective customers are worried that the distribution of profits and losses in Islamic banks will negatively affect their financial investments. Therefore, according to Rahayu, the factors that drive conventional banks low and the pull factor from Sharia banks are also low. So Muslim customers are less likely to turn to sharia banks (Rahayu et al., 2020). This research reinforces previous findings that Islamic bank customers in Indonesia are very concerned with the price difference. In order to compete, Islamic banks need to be a focus on the price.

In addition to higher pricing issues, pricing in Islamic banks has adopted conventional pricing such as BLR, KLIBOR, COFI, LIBOR, etc. The determination will affect the cost of fundraising, which will consequently affect investment income. According to Ahmed et al. (2018), Islamic banks should have their own Islamic Pricing Benchmark (IPB), the benchmark to determine the capital cost, because conventional benchmarks have been relying on interest rates that are very contrary to the Islamic economic system (Ahmed et al., 2018). 


\section{Promotion}

Promotion is one of the 4P marketing mixes. The promotion covers various tools such as advertising, personal sales, direct marketing, public relations, etc. Promotion refers to a series of activities that communicate the benefits of a product, service, or brand to persuade a target customer to buy it (Ahmed \& Rahman, 2015).

Furthermore, promotion is considered one of the ways used to spread and increase market share. Islamic banks must adopt new competitive and innovative promotions to win the market as customer demand increases and sustainable competitive growth. Studies from Muhammad et al. (2019) show that UAE consumer attitudes towards Islamic banking products are strongly influenced by active sales engagement and representative use of social media in promotional activities implemented by sharia banks based in the UAE (Muhammad et al., 2019).

In the context of Islamic banking in Malaysia, a study conducted by Kader et al. (2015)its returns and its physical image. Analysis of Variance (ANOVA shows that religious motivation is a very significant consideration for customers to make a decision. When there are many choices of banks that are subject to sharia, service satisfaction, attractive fees, and the provision of a good bank atmosphere will be the customer's choice. Therefore, Islamic banks need to promote that banks operate under sharia principles and increase the services, costs, or benefits received by customers and a good atmosphere or place for customers. Because the place will represent the reputation of sharia banks themselves (Kader et al., 2015)its returns and its physical image. Analysis of Variance (ANOVA.

4. Place

The place is a delivery and distribution center that connects customers and sellers. The place is an integral part of the exchange of services or the promotion for the final value of the marketing process delivered. In the context of financial services, Islamic bank branches are considered places or 
distribution channels. So in this article, the author will see the Islamic bank branch to contextualize this marketing mix. Previous research has identified the problem of access for the community is the place. The quantity of Islamic bank branches is considered inadequate for customers, so that access to Islamic banks becomes difficult. For example, the UK has one Islamic bank, namely Al Rayan, with ten branches and a Muslim population of 2.7 million people (Riaz, 2016).

As a solution to low access to Islamic banks, other research recommends that Islamic banks implement online strategies. The internet banking system does not require physical existence. Its existence can be accessed without any time and place restrictions. However, the key to success in providing services such as automatic teller machines (ATMs) depends on branch location factors, such as population characteristics, commercial, the proximity of other commercial outlets (Alquradaghi, 2013).

Other research conducted by Selamat et al., cited by Kader et al. (2015), revealed that bank customers in Malaysia emphasize fast and efficient service, bank reputation, image, and confidentiality as the top priority of choosing a bank. Therefore, Islamic banks must reflect the values of effectiveness, efficiency, security, and comfort in their places. If the place is a distribution channel that brings together customers and sellers/organizations, then the social networking platform can also be used as a marketing mix representing the place in this article. Previous research on social networks in Islamic banks' marketing has proven that Islamic banks have been using traditional marketing tools more often. So Islamic banks lag in adopting the latest information exchange technology compared to conventional banking systems (Naeem, 2019). Naeem (2019) recommends that it is necessary for IT professionals who can provide solutions for customers to access and also Islam bank safety. More than that, IT professionals can collaborate with the marketing department to improve the community's Islamic 
bank brand through text, audio, and video.

\section{CONCLUSION}

In terms, ethics is a set of moral principles that distinguish between right and wrong. In Islam, business ethics is absolute that has been regulated in the Qur'an and Sunnah. The theory of Islamic bank marketing ethics in Islamic principles plays an important role in bridging the gap between normative and descriptive things because it can project the strength of these two theories. Furthermore, by carrying out Islamic principles in their operations, Islamic banks actively gain sympathy from Muslims and non-Muslims. It is also able to survive during the crisis conditions.

In the context of the $4 \mathrm{P}$ frameworks (Product, Price, Place, and Promotion) or marketing mix, this article found that there are still shortcomings in Islamic bank marketing's ethical practice in its operations. In the literature on products, generally, financing products are still dominated by debt receivables. Ideally, the financing product is in the form of profit-share contracts. Furthermore, the literature on price has two important issues that can be found: Islamic bank prices are more expensive than conventional and Islamic bank adoption practices towards conventional bank pricing such as BLR, KLIBOR, COFI and LIBOR. The benchmark still relies on interest rates that are contrary to Islamic economic principles. Then the promotion literature found that Islamic banks still use religious sentiment in attracting the public's attention. In fact, Islamic banks have reliable performance and a reputation for conducting promotions. Lastly, this article found that Islamic banks cannot reach or provide easy access services to their customers about place literature. Similarly, the lack of IT utilization should be a solution to the limitations of the place owned by Islamic banks.

This conclusion can be seen as constructive criticism in the viewpoint of a limited marketing mix, especially in the amount of literature. Similarly, the findings that Islamic bank marketing ethics can still be refined in a better direction. Thus, this study's results may not describe the overall issue of ethical awareness 
within Islamic banks that should cover the other side of attention. There are still opportunities for further studies related to marketing ethics in Islamic banks that include literature and other marketing mix elements.

\section{REFERENCES}

Abbas, A., Nisar, Q.A., Mahmood, M.A. H., Chenini, A., \& Zubair, A. (2019). The role of Islamic marketing ethics towards customer satisfaction. Journal of Islamic Marketing, 11(4), 1001-1018. https://doi.org/10.1108/JIMA-11-2017-0123

Ahmed, E. R., Islam, M. A., Amran, bin A., \& Alabdullah, T. T. Y. (2018). Proposed the pricing model as an alternative Islamic benchmark. Benchmarking, 25(8), 2892-2912. https://doi.org/10.1108/BIJ-04-2017-0077

Ahmed, S., \& Rahman, M. H. (2015). the Effects of Marketing Mix on Consumer Satisfaction: a Literature Review From Islamic Perspectives. Turkish Journal of Islamic Economics, 2(1), 17-17. https://doi.org/10.15238/tujise.2015.2.1.17-30

Alquradaghi, B. A. (2013). The 7 Ps`In the Websites of Qatari Banks. Journal of Management and Science, III(2), 191208. https://doi.org/10.26524/jms.2013.25

Beekun, R. I. (1997). Islamic Business Ethics. In The International Institute of Islamic Thought. The International Institute of Islamic Thought. https://doi.org/10.2307/j.ctvk8w1zv.4

Beekun, R. I., \& Badawi, J. A. (2005). Balancing ethical responsibility among multiple organizational stakeholders: the Islamic perspective. Journal of Business Ethics, 60(2).

Bruin, L. De, Roberts-lombard, M., \& Meyer-heydenrych, C. De. (2020). Internal marketing, service quality and perceived customer satisfaction An Islamic banking perspective. Journal of Islamic Finance, 12(1), 199-224. https://doi. org/10.1108/JIMA-09-2019-0185

Caner, D., \& Banu, D. (2014). An Overview and Analysis of Marketing Ethics. International Journal of Academic Research in Business and Social Sciences, 4(11), 151-158. 
https://doi.org/10.6007/ijarbss/v4-i11/1290

Chonko, L. B., \& Hunt, S. D. (2000). Ethics and marketing management: A retrospective and prospective commentary. In Journal of Business Research (Vol. 50, Issue 3, pp. 235244). https://doi.org/10.1016/S0148-2963(00)00175-2

Elmawazini, K., Khiyar, K. A., \& Aydilek, A. (2020). Types of banking institutions and economic growth. International Journal of Islamic and Middle Eastern Finance and Management, 13(4), 553-578. https://doi.org/10.1108/ IMEFM-09-2018-0304

Fianto, B. A., Gan, C., Widiastuti, T., \& Sukmana, R. (2020). Customer loyalty to Islamic banks: Evidence from Indonesia. Cogent Business and Management, 7(1). https:// doi.org/10.1080/23311975.2020.1859849

Gundlach, G. T., \& Murphy, P. E. (1993). Ethical and Legal Foundations of Relational Marketing Exchanges. Journal of Marketing, 57(4), 35. https://doi.org/10.2307/1252217

Hamid, A., \& Zubair, M. K. (2019). Implementasi Etika Islam Dalam Pemasaran Produk Bank Syariah. BALANCA: Jurnal Ekonomi Dan Bisnis Islam, 1(1), 16-34. https://doi. org/10.35905/balanca.v1i1.1037

Hamza, H. (2013). Sharia governance in Islamic banks: effectiveness and supervision model. International Journal of Islamic and Middle Eastern Finance and Management, 6(3), 226-237. https://doi.org/10.1108/ IMEFM-02-2013-0021

Hunt, S. D., Wood, V. R., \& Chonko, L. B. (1989). Corporate Ethical Values and Organizational Commitment in Marketing. Journal of Marketing, 53(3), 79. https://doi. org/10.2307/1251344

ICD. (2020). Progressing Through Adversity. https:// icd-ps.org/uploads/files/ICD-Refinitiv IFDI Report 20201607502893_2100.pdf

Kader, R. A., Zakaria, R. H., Razali, N., \& Abdullah, N. (2015). 
Why This Bank? : Understanding Customers' Preference for an Islamic Bank in a Competitive Market. Journal of Islamic Economics Banking and Finance, 10(2), 138-153. https://doi.org/10.12816/0025174

Kamarulzaman, Y., \& Madun, A. (2013). Marketing Islamic banking products: Malaysian perspective. Business Strategy Series, 14(2-3), 60-66. https://doi. org/10.1108/17515631311325114

Kamla, R., \& Rammal, H. G. (2013). Social reporting by Islamic banks: Does social justice matter? Accounting, Auditing and Accountability Journal, 26(6), 911-945. https://doi. org/10.1108/AAAJ-03-2013-1268

Khaki, A. R., \& Sangmi, M.-D. (2012). Islamic Banking: Concept and Methodology. SSRN Electronic Journal, March 2019. https://doi.org/10.2139/ssrn.2184856

Lim, W. M. (2020). A marketing mix typology for integrated care: the 10 Ps. Journal of Strategic Marketing, 00(00), 1-17. https://doi.org/10.1080/0965254X.2020.1775683

Mansour, W., Ben Jedidia, K., \& Majdoub, J. (2015). How ethical is islamic banking in the light of the objectives of islamic law? Journal of Religious Ethics, 43(1), 51-77. https://doi. org/10.1111/jore. 12086

Muhammad, A. M., Basha, M. B., \& AlHafidh, G. (2019). UAE Islamic banking promotional strategies: an empirical review. Journal of Islamic Marketing, 11(2), 414-431. https://doi. org/10.1108/JIMA-10-2018-0205

Murphy, P., Laczniak, G. R., \& Wood, G. (2007). An Ethical Basis for Relationship Marketing: A Virtue Ethics Perspective. In European Journal of Marketing (Vol. 41, Issue 1). DOI.

Musa, M. A., Sukor, M. E. A., Ismail, M. N., \& Elias, M. R. F. (2020). Islamic business ethics and practices of Islamic banks: Perceptions of Islamic bank employees in Gulf cooperation countries and Malaysia. Journal of Islamic Accounting and Business Research, 11(5), 1009-1031. 
https://doi.org/10.1108/JIABR-07-2016-0080

Naeem, M. (2019). Understanding the role of social networking platforms in addressing the challenges of Islamic banks. Journal of Management Development, 38(8), 664-680. https://doi.org/10.1108/JMD-04-2019-0107

Nienhaus, V. (2011). Islamic finance ethics and Shari'ah law in the aftermath of the crisis: Concept and practice of Shari'ah compliant finance. Ethical Perspectives, 18(4), 591-623. https://doi.org/10.2143/EP.18.4.2141849

Ozatac, N., Saner, T., \& Suzmen, Z. (2016). Customer Satisfaction in the Banking Sector : The Case of North Cyprus. Procedia Economics and Finance, 39(November 2015), 870-878. https://doi.org/10.1016/S2212-5671(16)30247-7

Palmatier, R. W., Houston, M. B., \& Hulland, J. (2018). Review articles: purpose, process, and structure. Journal of the Academy of Marketing Science, 46(1). https://doi. org/10.1007/s11747-017-0563-4

Rahayu, S., Hati, H., Gayatri, G., \& Indraswari, K. D. (2020). Migration ( Hijra ) to Islamic bank based on push-pullmooring theory: a services marketing mix perspective. Journal of Islamic Marketing. https://doi.org/10.1108/ JIMA-07-2019-0157

Rama, A. (2020). Strategic pricing by Islamic banks and the impact on customer satisfaction and behavioral intention. Journal of Islamic Accounting and Business Research. https://doi.org/10.1108/JIABR-04-2019-0078

Rashid, M., \& Hassan, M. K. (2014). The Market Values of Islamic Banks and Ethical Identity. American Journal of Islamic Social Sciences, 31(2), 43-74. https://doi.org/10.35632/ ajiss.v31i2.289

Riaz, M. (2016). Islamic Marketing Ethics and the Marketing Practices of Islamic Banks. ISRA International Journal of Islamic Finance, 8(2), 27-49.

Saeed, M., Ahmed, Z. U., \& Mukhtar, S. M. (2001). International 
marketing ethics from an Islamic perspective : A valuemaximization approach. Journal of Business Ethics.

Schottmann, S. A. (2014). From duty to choice: Marketing Islamic banking in Malaysia. South East Asia Research, 22(1), 5772. https://doi.org/10.5367/sear.2014.0189

Snyder, H. (2019). Literature review as a research methodology: An overview and guidelines. Journal of Business Research, 104(July), 333-339. https://doi.org/10.1016/j. jbusres.2019.07.039

Sonko, M. (2020). Customers 'Perceptions on Islamic Banking : A Case Study in the Gambia. Journal of Islamic Finance, 9(1), 13-23.

Thabit, T. H., \& Raewf, M. B. (2018). The Evaluation of Marketing Mix Elements: A Case Study. International Journal of Social Sciences \& Educational Studies, 4(4), 100-109. https://doi.org/10.23918/ijsses.v4i4p100

Ur Rehman, A., Aslam, E., \& Iqbal, A. (2021). Intellectual capital efficiency and bank performance: Evidence from islamic banks. Borsa Istanbul Review. https://doi.org/10.1016/j. bir.2021.02.004

Wilson, R. (2002). Parallels between Islamic and ethical banking. Review of Islamic Economics, September 2001, 1-13. http:// www.kantakji.com/fiqh/Files/Banks/b082.pdf

Wozniczka, J. (2016). The ethical dilemmas in marketing-the positive idea and its desirable and undesirable consequences. Oeconomia, 15(4), 195-207. 